\title{
COMMUNICATIONS
}

\section{RESPONSES TO QUESTIONS ON THE FIRST ANNIVERSARY OF OCCUPY WALL STREET}

\author{
James Craven and Xinning Zhang
}

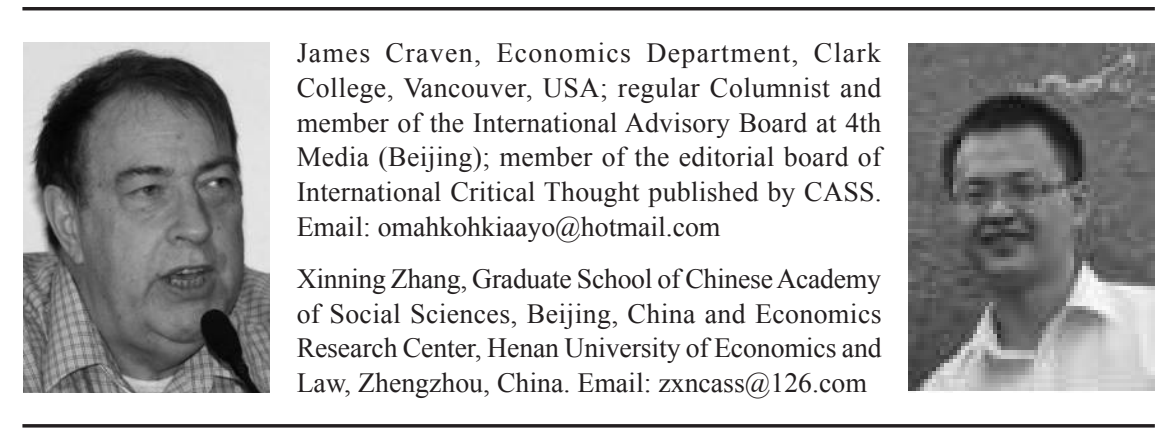

Note: Occupy Wall Street (OWS) has been the first large-scale, ideologically diverse and spreading protests since the 1970s in the US. On September 17, 2012, protesters assembled near the New York Stock Exchange to commemorate the first anniversary of OWS. In the meantime, marches and rallies were held in more than 30 cities worldwide. Demonstrators protested social injustice ignited by insatiable corporate greed of banks and financial institutions like Wall Street and the protesters are still angry over issues such as that their homes are underwater, that the economy is in disarray due to the ineffective supervision of the American government. To view OWS in a clearer and deeper sense, Xinning Zhang interviewed Prof. James Craven at Clark College, Vancouver.

\section{On Developments of the OWS over the Past One Year}

Xinning Zhang: Dear Prof. James Craven, thanks for your responses to my questions on the first anniversary of Occupy Wall Street. As we see it, since it began on September 17, 2011, OWS has been viewed as an anti-capitalist protest; or as a broad-front and leftist protest, targeting the likes of the American Tea Party. Parallels are sometimes given with other movements in terms of demonstrations organized by mostly young people, with advanced social networking technology, to show their 
dissatisfaction on a wide range of issues such as those raised in the so-called "Arab Spring" demonstrations or in the protests against high unemployment in Madrid. Participants typically range from the unemployed, college students, babysitters, nurses, bus drivers, to general employees, etc. Political paradigms range from liberals, middle-of-the-roaders, socialists and some types of conservatives, to anarchists and libertarians. How can we understand the various claims, paradigms as well as forms and levels of participation of the diverse protesters?

James Craven: First of all I still see no evidence of a real "Movement"-yetonly a "Moment"; or, perhaps, several "Moments," linked mostly by a common label across the country, with some demonstrations on symbolic dates mostly of significance to commemorate previous actions and/or that have mostly been conferred as "significant" by the "mainstream media" ["MSM"]. And I do not see strong parallels yet between the OWS "Movement" and the "Arab Spring" demonstrations or demonstrators on several levels. I do not believe that many of those in OWS could or would be capable of facing the levels of violence and state repression that those in the "Arab Spring" demonstrations have faced. In places like Egypt, Yemen, Tunisia and other places the level of state violence and repression are far beyond anything the typical OWS protester has ever faced.

Many of the "Arab Spring" demonstrations are focused against regimes that were installed, supported, protected by US imperialism; regimes that, by the way, were once trusted to act as destinations for accused "terrorists" under "Extraordinary Rendition" by the CIA. They were chosen for outsourcing torture forbidden by US law while also being targeted in some cases for "regime change" [as alleged regimes (e.g., Libya and Syria) that routinely carry out torture they were sent prisoners by the US government (USG) to do what the USG claimed was a reason for wanting regime change - torture]. Yet many of those involved in regime change among the "Arab Spring" protesters and insurgents are still begging the same forces of U.S. imperialism for support, appealing to "American-style democracy" and "human rights" that were behind installing and/or protecting and collaborating with the very regimes they want to change. And the demonstrators involved in the "Arab Spring" demonstrations, among whom Al Qaeda elements are surfacing and taking control, are not "pro-democracy," pluralists, or whatever; many are not expressing anti-capitalist or even anti-imperialist sentiments or demands so much as for simple regime change and "reform" to some system as yet unspecified in any detail.

Perhaps if there are parallels they are in the area of shared illusions with those in OWS who appear to have some notion that if you replace a few key individuals, or pass some new sets of laws, all of a sudden, history is gone, and all that history has handed the present is gone; a new system with new outcomes is supposed to pop up, and take root, to start producing new outcomes being demanded immediately. 
From OWS protesters, we often hear something like: "Where is MY job?"; "Why can't I get a bailout for MY mortgage?"; "Why can't I get a bailout on MY student loan?" And in the same fashion, some of those in the "Arab Spring" and related insurgencies are saying: "We want regime change in OUR country; even if it means in alliance with the very forces of imperialism and reaction ("the enemy of my enemy is my friend' mentality) that installed the very despotic regimes we now demand to be removed." And some appear not to care if they are promoting myths and lies about the real nature of imperialism and its effects on other nations and peoples with their begging for direct and open US and allied support for their insurgency. In both cases there appears a kind of self-centered myopia about imperialism and its real nature, victims, logic, interests, and intentions globally.

By "Movement," with a capital "M," I mean some organized body of people, with some common issues and interests of focus, as well as structures and mechanisms for collectively deciding such defining the core dimensions of any Movement. These dimensions include: leadership; platforms; tactics and strategy; funding for ongoing sustainability and activities; internal decision-making and carrying out, reviewing and refining decisions; connections with other Movements and organizations; mechanisms for security of the organization and recruitment-training of new members; and the like. None of that is really present within any of the particular "Occupy" demonstrations, or groups within them, past and present. Any serious ongoing organizational links between the "Occupy" forces in different cities inside America and with those outside as well, appear to be absent and/or sporadic and mostly on levels of personal and sect relationships. The main focus of the various "Occupy" actions in New York City and throughout America appears to be on the "politics of the deed"; there are also some teach-in activities and spontaneous "street theater" of emotion and action. This is typically followed by periods of inaction and "non-occupation" around various key events and demonstrations.

As in some of the parallel demonstrations abroad related to the so-called "Arab Spring," they appear to involve very diverse sub-groups, with no shared leadership or any kind of coherent whole organization, who have come together via social media, around some common actions and grievances and against common perceived enemies and their regimes. They do not appear to have solidarity or common actions around any kind of coherent plan or program to define what they oppose and to articulate some alternative vision of, and replace, what they purport to demonstrate against. That is one of the critical differences between a "Moment" and a "Movement." History records all sorts of Moments of various forms of resistance that had some potential to be turned into Movements; but few that turned into sustained Movements over time.

What I see so far in OWS and related demonstrations elsewhere, is a kind of mélange of different individuals, political sects, and single-issue organizations 
gathering together at places, and on dates, with symbolic significance mostly to themselves. Demonstrations are essentially annual reunions or "anniversaries" of previous ones. Never mind that some of the previous ones appeared as empty and unfocused, or theatrical and carnival-like, as the present ones. We find themes [multiple] and memes [thought viruses] representing some of the usual infantile and often alienating chants and rants that rhyme [e.g.: "1, 2, 3, 4, we don't want your $\mathrm{f}^{*}$ cking wars..."; " $5,6,7,8$, time to smash the $\mathrm{f}^{*}$ cking state"] with various single-issue contingents in full regalia. There appears to be a whole lot of standing around waiting for someone to assert something or some kind of "leadership" and then some resenting them when they do.

There also appears to be no real or coherent outreach to the wider public that they seek to recruit and mobilize [efforts to have dialogue with public observers not part of the demonstrations]. This last OWS demonstration was timed to mark the first-year anniversary of the OWS demonstrations in New York City. But other "Occupy" demonstrations took place prior to that one in New York City, and/or at the same time, and/or subsequent to it in other parts of America and the world. I have not been to the Occupy site in New York City, but I am in contact with those who have been and/or are presently involved with OWS there. I attend and participate in the demonstrations in Seattle; Vancouver, Washington; and in Portland, Oregon. I read the websites and their supporting materials. But still I am making provisional observations and generalizations to which there are of course notable exceptions; exceptions however that appear to showcase rather than refute the generalizations.

The demonstrations at OWS are all pretty much the same in terms of demographics as in other parts of the US. According to two studies of note, at OWS in New York City, the average age of protesters has been in their early thirties (those in their twenties balanced out by those in their forties). Among the most visible and theatrical are some anarchists and new left activists from supposed "anti-hierarchical," "antiauthoritarian," and "consensus-based" politics; some are from other "prefigurative" or "anti-vanguardist-party" politics. They appear proud not to have an evolved and identifiable leadership or spokespersons to the media; and each spokesperson makes a point that he or she is speaking personally, or for one of the groups, but not as a spokesperson for any whole "Movement." And in terms of race and ethnicity, and why African-Americans were underrepresented [not a word about Indians as usual], one study showed $81.2 \%$ white, $6.8 \%$ Hispanic, $2.8 \%$ Asian, $1.6 \%$ Black, and $7.6 \%$ identifying as "other." Gender ratios are not reported but males appear to outnumber females in general.

Many of the signs and issues appear to reflect narrow issues, or issues narrowly seen, presented and disarticulated from other issues. Some of the issues are: wealth-income inequalities; fiscal crises; job outsourcing; deficits and debt; student debt forgiveness; inverted mortgages and housing crises; high and hidden 
unemployment; unconscionable personal foreclosures. They are all effects of a whole system and related in reality; but these and other related issues are also often narrowly seen and presented by other - and even competing — constituencies. This leads to fundamentally contradictory overall platforms beyond single-issues in common (like leftist anti-Zionists having anything to do with rightist, even fascist, antisemites calling themselves also "anti-Zionists").

For example, when I was in the US Army in 1963-66, and homophobia was much more pronounced and deadly than today, I knew personally individuals who were heterosexuals and played at being homosexual, as well as homosexuals who "outed" themselves, at great risk and cost to themselves and their futures, in order to avoid their going to Vietnam and participating in the war crimes of another genocidal war, or imperial social systems engineering campaign (like Iraq, Afghanistan, Syria, Iran, Libya, etc....) founded on lies, phony and engineered pretexts, faked intelligence and the like-what the Vietnam War was also. And they were not pacifists, and they were not just afraid of war; they actually articulated anti-Vietnam sentiments in the military. Of course there were also homosexuals who hid their preferences in order to go to Vietnam and kill as well.

Now we see, including in the OWS demonstrations, advocates of LGBT (Lesbian, Gay, Bisexual and Transgender) rights, demanding the end of "Don't Ask, Don't Tell" policies against homosexuals in the military; with demands to open the military to LGBT individuals "serving" in the US military. There are even some "feminist" demands for women to be allowed in combat [in order to become competitive with the males for promotions with combat experience]. From this narrow constituency, for example, no mention is made that they are demanding, in essence and reality, to serve in imperialist wars founded on lies, wholesale violations of international law, and war and other crimes of the kind that Nazis were hanged for at Nuremberg. They push for no discrimination in the military primarily not only to end discrimination against LGBT persons, but also to become more a recognized part of the "mainstream" of society. But that begs a fundamental question: "mainstream" of what? What does it mean to be "mainstream" in Nazi Germany? It means one is likely a Nazi in thought and deed. What then does it mean to seek to be less "on the margin" of a society, or its military institutions, but with no reference to the real nature of the system of that society? What does it mean to demand equal access to one of its institutions like the military, that is fundamentally corrupt and involving decaying systems built on imperialism, war, genocide, and serial denial of rights to many others? It is like narrow feminists seeking, and even defining as "women's liberation," an "equal opportunity" for women to become torturers at Guantanamo or at one of the secret prisons the CIA has stashed all over the world.

In other words, many at these demonstrations have been basically demanding the "right" to an "equal opportunity" to become an oppressor and willing tool of US 
imperialism. The demand for "Jobs, Jobs, and Jobs" includes also becoming a career tool and servant of US imperialism with no regard to, or concern for and about, the victims of US imperialism from past and present blowbacks and those clearly being planned for the future. That is why the sign that my son and I carry says:

\author{
Liberty \\ $\neq$ \\ "Equal Opportunity" \\ To Become an Oppressor: \\ Oppose U.S. Imperialism \\ In Our Name \\ (Covers All Pet Causes)
}

In his play The White Plague, Sean O'Casey's character notes: "Nothing is so passionate as a vested interest disguised as an intellectual conviction."

This principle is evident in so many of the Occupy demonstrations in various cities, and in the signs and demands reflected in them. We see students demanding lower tuition fees, student debt forgiveness and more jobs available when they graduate. But we see little or nothing about gross inequalities faced by minorities in access to quality education. We do not even see any questioning if, in fact, the traditional Ivy League schools really do represent "quality education" [or what that means] as opposed to being the brand-name ideological clone factories of imperialism and capitalist privileges that they are and always have been. There were even some signs at OWS protests against immigrants, illegal and otherwise, as "job stealers"; and even some anti-affirmative action signs alongside of them that use some of the same slogans and memes of the right wing in the US. There is an old saying that "a conservative is a former liberal that has been mugged [robbed] and a liberal is a former conservative who has been downsized or outsourced."

We see some trade unionists, well-paid union bosses, and laid-off workers demanding jobs back, job retraining, extensions of unemployment benefits and to stop outsourcing jobs (often with a focus on bashing China as "taking 'our' jobs"). In fact, this is how the Democrats, traditionally seen as "soft" on defense and national security, pass off their versions of acceptable forms of "tough talk" on national defense issues: China bashing. Even some of the so-called "leftist academics," who denounce or call into question generic capitalism as a viable and sustainable system, in their "sage tomes" and writings, have created a whole specialized "Left-Chinabashing" academic-market-niche (journals, books, essays, websites) as they seek and even gain, some kind of "legitimacy" and place in academia by also engaging in their own forms of China bashing. They often repeat in their chants, rants and signs, some of the most vile slander and libel of even the 1950s against China. 
And I see no evidence of any knowledge or understanding on the part of some of these sage leftist academics and protesters, parroting some of the same memes and themes of the rightists, of just what China has had to endure, and still has to endure, from the machinations of US imperialism that have handed some of these relatively privileged academics and labor aristocrats crumbs and privileges yet that few anywhere on earth enjoy.

Xinning Zhang: If deficits and debt (absolute levels or as shares of GDP) are an issue, then how should we view China as a significant holder of that debt? Why is the debt owed to Canada, Germany, Britain or Japan not seen as threatening? And what about the real issues in reference to budget deficits and debt: how and for what and whom is this debt used? Is the debt being used to build productive capacity and competitiveness in the global economy or to fuel illegal wars that destroy productive capacity and competitiveness globally? What evidence is there that China has ever been any kind of threat to the US or other nations? What if China recognized part of America controlled by separatist and secessionist forces, as a separate nation, set up bases on the borders of America, and launched continual covert and overt military operations against America? What if China proposed UN membership for some secessionist entity from America or even proposed that this entity that China helped to create as now the only "true representative" of all of America?

James Craven: This was all done and is still being done to China (Taiwan, Xinjiang, Tibet, Yunnan, Macao, Hong Kong) and to other nations as well as part of global campaigns of imperial social systems engineering, encirclement, destabilization and regime change - overt and covert. US imperialism has always believed in the notion of no neutrality and "you are either with us [as we only define what it takes to be "with us'] or against us."

This is not the past; it is the present and intended future. And when I raised some of these issues with fellow demonstrators (e.g., some carrying Tibet secessionist signs), one demonstrator appeared to resent any change in "focus" of the demonstrations from his notion of the immediate demand for jobs, debt forgiveness, mortgage adjustments, make the rich pay higher taxes, etc., to what they saw as the more "abstract" and "distant" demand: to end all support for US imperialism carried out in the name of those demonstrating.

This is even as China is a past, present and intended future victim of US imperialism. Instead China is cited as an enemy or potential enemy, with rhetoric as vile as any of the Cold War rhetoric of the 1950s and 1960s, and with China (used to be Japan also non-white) mentioned as a specially problematic and threatening holder of US debt, US dollars and a destination of US jobs. Never mind that China never forced anyone in the US to borrow to finance out-of-control deficits and 
debt fueled by two illegal wars and weapons build-ups partly clearly aimed at encirclement and containment of China. Never mind that China's lending helps to keep those interest rates on student, consumer, and mortgage and government debt lower than they would be. Never mind that China has been a victim of imperialism and colonialism since the early $1800 \mathrm{~s}$. Never mind that China is still on an active target list of nations, a constant target of weapons systems in constant readiness, in case of nuclear war no matter who is involved; while China, a reluctant nuclear nation, has a no-first-use policy on nuclear weapons and China is the only nuclear nation to have such a policy.

I see some of the same forms and "doctrines" of entitlement, exclusivism, triumphalism, exceptionalism, Calvinist-like predestination and elitism pushed by the US imperium globally and nationally. I see some of the same hubris on smaller and microcosmic scales among some of the OWS demonstrators. For example, many signs carry references to having university degrees but yet being "forced" to do "menial labor" or forms of physical labor seen to be "below" and "not" what they trained for at university. There are references to some mythical "American Dream" that, when deconstructed, turns out to be some stereotyped version of middle-class suburbia: kids do better than their parents; a house with a low-interest mortgage; "good job"; kids who go to "good schools" that are well funded; jobs waiting upon graduation from college; etc. I see and hear repeated references to the memed "American Dream" even by the demonstrators claiming that: "if you work hard, play by the rules, live a clean life, believe in God, the system will deliver for you in terms of a happy and productive life." Many of the demonstrators claim this was once the case in America and now this "American Dream" has been somehow "hijacked, stolen, lost misplaced," or something — by the $1 \%$ or someone...

Xinning Zhang: Then how to explain whole populations, or large segments of whole populations, that have been left destitute for the whole of American history: American Indians; African-Americans; Latinos; women? Do they just lack the drive, ambition, will, ability, and desire to "obey the law" and "play by the rules"? And what about those small segments of certain groups, the ones from family trees "that do not branch," the "inbreds," with names like Rockefeller, Lord, Bush, Whitney, Weyerhaeuser and that can be found at venues like Davos, Bilderberg, Bohemian Grove, Trilateral Commission, Council on Foreign Relations, and the like; from families who built their empires through opium, arms trafficking, imperialism, war? What about these types not playing by even their own rules and not even obeying the very laws they wrote in their own favor to be obeyed by others?

James Craven: Yes, indeed. That is the logic. If these myths of "upward mobility" apply for all those who work hard and play by the rules, then how to explain the poor 
and destitute? But the reality is even much deeper than these self-congratulatory and dangerous myths being promoted by some supposed leftist demonstrators. The social formation of America and its interdependent dimensions (economy, politico-legal, historical-geographic, and social-cultural spheres of the whole social formation) in fact, was founded on genocide, colonialism, plunder, entrenched privilege and inequalities, slavery, rank hypocrisy, that exist and persist today. There never was the America or "American Dream" that some claim has been "lost" or "stolen"; not for the broad masses of people. Howard Zinn's The People's History of the United States tells a very different history than what is peddled in the school system and even by some of those academics and protesters themselves who have their own revisionist versions of history. And as an American Indian, I can tell you many stories about hubris and racism and patronizing from elements of the American "Left" that are as vile, perhaps more so because they claim to know better and to have different values as anything from the Rightists they say they oppose. I have not seen one sign protesting the "American Holocaust" against Indigenous Peoples but for one example.

In the original US Constitution, Blacks counted only as $60 \%$ of a person; but that was only for census purposes to increase the population base and representation in Congress of the Southern slave-holding states. American Indians were asserted to be "dependent and captive nations"; to be either assimilated by force or "extirpated" [wiped out in toto]. Women could not vote; and even white age-eligible males could not vote unless propertied. And elites and chartered monopolies ruled from the very beginning and set up a system that guaranteed that the rich few could rule the many through the law, and without even having to break the law in most cases. And if they did break the law, their punishment for their real crime — getting caught—would not ever be like that of the masses.

I see few references in the signs, rants, and theatrics, even about de-classed workers, former middle-class; and the words and reference to "the poor" and chronic poverty in America appear to be absent. The primary focus appears to be on the declining middle-class, the supposed central reference in the presidential campaign as well.

There is the notion that America is, and was always, somehow destined, by God, or some amorphous "forces of history" even, to "world leadership" that is now being lost or threatened. "America-in-Decline" is a common theme and meme. We find whole special sections of literature at chain bookstores like Barnes and Noble, and in film and television, along with other typical "End-Times" or "End-of-Empire" topics as: "gambling; Lotto, and how to win"; occultism and occult mysteries; staying younger longer; "ancient prophesies of end-times"; 2012 and the Maya, biblical, and other "sacred texts" on coming "end-times"; rise and fall of empires past and present; survivalism: tools and tactics; financial investment strategies; etc. On the 
television there is a plethora of new television shows, movies, books and cults that glorify the CIA, FBI, NCIS, Homeland Security, Navy SEALS, Delta Force, NSA, and other covert agencies and forces of US imperialism. They all give the theme and meme of trading away [supposed or de jure] "personal liberty and rights" for personal protection from a monolithic and well-armed state that cannot be resisted and will crush you if you dare to resist, but will also use the same technologies of repression to protect you and keep you safe if you go along with compliance and non resistance to US imperialism in your name. These are all the classic historical signs of an empire in decay.

There is the widespread notion that yes, we should think and "Go Green" and be environmentally responsible; and we want the new Green jobs. But as for $5 \%$ of the world's population (Americans) using over $25 \%$ of the world's critical resources and energy, and generating and dumping almost $30 \%$ of the world's pollution, there is no mass call for serious reductions to US political, economic, and environmental footprints that are globally out of proportion to our share of the global population. We do not see much mass objection to: the brutality and terrorism of US imperialism globally; the grotesque inequalities in access to and use of global resources, as well as gross inequalities in the rewards of growth for a few but social costs of growth on the many. We see mostly demands for America and Americans to have a bigger share of the spoils from the national or global pies ("bring OUR jobs home") but with little regard to the nature, costs, and misery of imperialism that have been extracted from the many on a global level to obtain these economic and other pies from which the demonstrators appear to myopically want a larger share. They appear not to apply the $99 \%$ to $1 \%$ on a global scale and see that on the global level, in relative terms, they, middle-class Americans, are closer to the top 1\% than the $99 \%$ in terms of overall quality of life.

We see demands to "regulate" or "re-regulate" a generic Wall Street. But little said with any specificity on the core issues: regulation by and of whom?; regulation of what and in whose interest?; accountability under law by whom, to whom and how enforced? How can we even cite, to be obeyed, the very same law that was written by and for the $1 \%$ so they would not have to break it? There appears little notion of a fundamental contradiction in petitioning or begging for change, the very same plutocratic forces, elites, relations and laws (or absence of some laws and regulations) said, by the protesters themselves, to be among the fundamental forces and causes of the misery being demonstrated against. As Einstein put it: "It is not possible to solve any crisis with the same mind-set that caused it." Or, "insanity is doing the same things [with the same people in the same ways under the same conditions] over and over again — and yet expecting different results." 
Xinning Zhang: How can one rationally decry a state that is alleged by OWS to be bought and paid for by the "Top 1\%" or even the "Top 10\%," and yet be making demands, really begging, for "change 'we' can believe in," from these very same forces and agents in government that are alleged to be paid and career tools of the very plutocrats and plutocracy being protested against? What is supposed to make them change and betray those paying them?

James Craven: Exactly. It is like protesting against and asking Nazis and their system to reform and now, finally, do something about the evils of antisemitism. We see signs and slogans with demands: to stop foreclosures and restructure existing mortgages; to prevent future foreclosures and further collapses of housing markets and prices; to restructure consumer debt and eliminate unconscionable administrative fees of banks; for lower tuition fees and forgiveness of student debt. But little notice is paid to some of the petit-bourgeois "I-want-it-all-and-I-want-it-now" (from the title of a song by the English rock group, Queen) mentalities and behaviors by some that led to taking out mortgages, student and consumer debt that those now in distress should have known that there was no way they could handle the mortgage and other debt loads they undertook.

We have people protesting mortgage, consumer, and school and auto loan terms they wound up paying yes, partly, because they were desperate and given false promises; but also because they did not bother to read the "fine print" in the contracts they quickly signed and thus gave the banks open entry and season to exploit them. They often simply assumed, because they wanted to, that housing prices could never go down and thus each mortgage must create instant and ongoing equity (difference between estimated and supposed "inevitable" rising market "value" of a house minus the declining debt on the house) on which further borrowing could be made. The mortgage, they often were told and assumed, could be turned into a cash machine for consumer loans using the house with rising equity as collateral. And if worse comes to worse, it was expressed, of course the house can be sold at a profit and even the profit used tax free to rollover into a new house and to pay off any consumer loans. There is no mention of personal responsibility, greed, and illusions about the capitalist system and imperialism on the part of some of the demonstrators that were also involved in some of their own present misery and situations.

We see demands for cheaper gas and tuition, with not one word about the horrible price paid by so many innocents, all over the world; innocents suffering under dictatorships installed and maintained by the US imperium; innocents suffering as "collateral damage" in oil wars (all for relatively cheap gas at home to drive huge, gas-guzzling SUVs giving the illusion of "safety and "security" for "soccer Moms" in suburbia). That is who some of the demonstrators, mostly floaters and not occupiers, are. And many of their issues are direct personal issues such as home 
foreclosures, student debt defaults, bankruptcies, rising tuitions, outsourcing and the like. The more macro issues such as deficits and debt crises, scope and pace of economic "recovery," wealth and income inequalities widening and deepening, rising energy prices and "security" crises, appear all framed on the basic meme level (thought virus) with very little analysis of how to even properly measure, let alone assess the significance of, widening and deepening wealth and income inequalities or fiscal crises of the state etc.

In fact the issues raised by the typical demonstrators go way beyond those constituencies at OWS to those typically not represented on the signs, by particular victims or in their presences: American Indians; very poor and homeless women, children and men; abused children; foreign victims of US imperialism abroad and of some myopic "labor aristocracies" at home. Further, we see the homeless people, who often gravitate toward these demonstrations for food, panhandling, security of a group, to also participate or to actually do the occupying part of the demonstrations; and they are often marginalized and treated with contempt and unkindly by some of those supposedly demonstrating such concern for justice, compassion and jobs in the abstract. I saw this over and over and have seen it over my 40-plus years of activism. Homeless and poor people gravitated toward the warmth and security of the fires that were set in groups of encampments, and appeared to be immediately perceived to be and treated as "the other." They were typically pushed away, by some folks all while so very openly, loudly, narcissistically and piously proclaiming their "secular humanism" or faith on their signs and in their rants. My mother used to call such types of persons: "the ones whose 'bleeding hearts' bleed so publicly, so piously, so theatrically and dramatically, for an amorphous 'humanity' (in the convenient and safe abstract sense); but are actually often rather hateful, full of themselves and unkind to particular people in the concrete; and their "bleeding hearts' always 'bleed' safely and at a distance - and always with the blood of others."

The goals or demands in most of the Occupy demonstrations throughout the US appear to parallel those of OWS. Again, we see elsewhere typically signs demanding: student loan forgiveness and reductions of tuition fees; more and better jobs; regulation of Wall Street speculation and speculators; stop foreclosures of homes; reduce wealth and income inequality; stop bank bailouts and/or demands for bailouts for foreclosures and student debt like those given the banks. The slogan "We are the 99\%" gives an impression of fundamentally unified interests and homogeneity among this mythical $99 \%$ that will never completely occur as among the $99 \%$ are also some rightists, labor aristocrats, collaborators and tools of the top $1 \%$ or even $10 \%$; some of them workers and the like, who will never change and who help to keep that $1 \%$ in power.

We see continual references to some undefined mythical "American Dream" that has been supposedly "stolen," "hijacked," and "wiped out" but that never was always 
in reality an illusion and myth. But few of the signs call for ending US imperialism and wars founded on lies in their name. Few have signs calling for ending statesponsored terrorism by the number one source of it-US imperialism. Few call for ending prosperity in the West built and run on the backs of many victims paying in blood, war, misery, and victims of dictators abroad (for relatively cheap oil, secure spheres of influence and raw materials, and the like) as well as at home. Few appear to see the dialectical relationship between wealth and poverty - globally, nationally, and locally - under capitalism and imperialism. It is not a matter of concentrated wealth and income and or versus poverty, juxtaposed; it is about concentrated wealth and income because of poverty, and vice versa. In other words, there is a causality not just correlation between wealth and poverty. Concentrated wealth and income exist because of - and are dialectically fed by - poverty, and vice versa.

Xinning Zhang: Alan Greenspan, who chaired the Federal Reserve for the two decades from 1987 to 2006, could be counted upon to deliver himself such statements as this: "Those of us who support market capitalism in its more competitive forms might argue that unfettered markets create a degree of wealth that fosters a more civilized existence. I have always found that insight compelling. "Unlike any other movement on the American left for at least three-quarters of a century, the Occupy Wall Street movement began with a majority base of support. In the Occupy Wall Street movement, some revealed their attitudes painted on signs: "We are the 99 percent"; "I hate drum circles but I hate corporate greed more"; "I choose to be aware"; "You can't own land, it's just as silly as owning the stars"; "99 to One: Those are great odds. "So, according to you, how can we analyze such phenomena and explain the operation of the Wall Street system?

James Craven: Many argue in the demonstrations for reform, or restructuring, or more regulation of capitalism. And for some of them even the demand to reform capitalism is a step forward from where they were as blind apologists of capitalism in need of no reform. But few see capitalism and imperialism as the root of many of these "single issues" that are not "single issues" at all. They are interdependent and the likely results of the core and defining features, contradictions and relations of imperialism, a whole globalized system not just a set of policies, that shape the systemic "logic" driving the ups-and-downs (vicissitudes), trajectories and crises of imperialism as a whole at home and globally. Imperialism is not simply some set of policies; it is a globalized system of domination and plunder from which many at home in the metropoles of the imperium are both exploited and also beneficiaries (Lenin's concept of the "Labor Aristocracy" in the imperium) of the relative wealth extracted from abroad and brought "home." 
I see so far in this OWS Moment rather than Movement, that which is the usual buffet-style "radical activism" or "buffet socialism" so common in the ultraindividualistic and materialistic West. Here we find integral and interdependent parts and issues of a totality (imperialism and capitalism) are often treated and focused on as "single issues" like individual food items on a buffet. They are promoted by "activists" according to impacts on their personal lives or those of loved ones. Like a buffet at a restaurant: "take a little of one or another of the 'dishes' (causes or single issues) to sample, according to your tastes and preferences." It is sort of like the Telethons on television for various causes in which the movie stars are doing annual benefits for diabetes, cancer, multiple sclerosis, etc., depending upon which of those diseases hits the celebrity or his family personally. And it often comes off as whining, narcissism, selfishness, myopia, self-absorption and special pleading, etc., because that is what it really is in some cases or even many cases.

Further, demonstrations and the anarchist notion of the educational and inspirational values of "politics of the deed" can be very theatrical, spontaneous, fluid, gratifying in terms of personal ego and narcissism. Best of all, these demonstrations give instant gratification and the illusion of actually doing something tangible and seeing "results" in the relative immediate (in press coverage and in the mutual congratulations and triumphalism during and following such demonstrations). Perhaps something like: "Hi honey I'm home. Had a hard day at the old demonstration against war and for peace. I had a daring sign saying that war is evil; the cops took my picture; I was interviewed by a TV reporter and told her I am against war; and I was almost gassed when I told a cop I had rights and could stand where I wanted. This class struggle and standing up for American democracy is tough work."

Where mass work is slow, protracted and hard to measure the effectiveness of sometimes, it is indeed by its nature, especially living "inside the belly of the beast" in North America, a "Long March." Demonstrations, on the other hand, can give a sense of shared participation and having done something real with immediate and visible results for the cause. "Politics of the deed," an anarchist construct, also employed by terrorists, is the notion that specific acts, through their creative, theatrical and daring nature, supposedly politicize the masses immediately or almost so; and set in motion questioning of the system by its very supporters. This is an anarchist notion; and of course nowhere and at no time in history have anarchists ever made and sustained a revolution or ever built a sustained social formation out of a revolution.

The impotence of (quick, dirty, and relatively cheap) terrorism chosen in lieu of protracted (costly and dirty) insurgency against imperialism and occupation is mirrored by the impotence of counter-terrorism chosen in lieu of protracted counter-insurgency. Terrorism is attempted insurgency on the cheap just as counterterrorism is attempted counter-insurgency on the cheap (in terms of blood, treasure, 
and uncertain outcomes). Insurgency and counter-insurgency are about winning over "hearts and minds" which is a protracted and costly process; especially when the imperial tactics and strategy wind up making more enemies than friends and converts. Terrorism and its counterpart counter-terrorism, that often winds up as another form and source of terrorism, are in reality admissions of impotence and come from a need for some kind of immediate, dramatic, and face-saving results that will then allow withdrawal from a conflict to be framed as "with honor" and as "Mission Accomplished." The same applies to Moments passed off as Movements that basically involve demonstrations and demonstrators and little else in the area of protracted mass work. It is an admission of impotence and inability to reach out to, listen to, relate to, link up with, those abstract masses, the many millions who will not go to any demonstrations, but who are supposedly among the undefined and mythical "99\%" being "represented" in the demonstrations. Demonstrations can be emotionally gratifying, can be photographed to show "proof" of commitment by physical presence, and they give a kind of feedback that is relatively immediate.

When you look at the messages on many of the signs, they often mirror the national narcissism, exclusivism and exceptionalism for which "American culture" is often portrayed, caricatured, and hated by many globally. The signs are often really saying: "ME, ME, ME"; "Look at ME"; "MY special issue and cause is most critical and in need of funding [as "evidenced" by how big my sign is and how loud my "bull-horn" or speaker is]; "MY struggles and those of MY people need to be heard"; "MY disease deserves special funding for research"; "MY crisis du jour deserves special attention NOW!"; "MY distress needs to be alleviated no matter what resource constraints, no matter what my own hand in my present distress (e.g., taking out student loans, home mortgages, consumer loans, no concern with no realistic ability to repay or effects of potential loss of job) and no matter what other forms and sources of distress faced by others who are also competing for scarce resources to alleviate distress, clean up disasters, or prevent future forms of distress and disasters." These are the real statements often behind or implied in the slogans, rants, memes, and themes often articulated in mass demonstrations in the West. They reflect the selfishness, greed, ultra-individualism and petit-bourgeois mentalities that infect large segments of the "Left" in the West who often think they are somehow immune from the effects of living under capitalism on mass consciousness and the forms of rank individualism and selfishness they have also internalized and are expressing.

The single-issue nature of many of the demands on the signs carried by OWS demonstrators, come from the soil, culture, core "values" and institutions - and imperatives - of capitalism and imperialism as systems. We in the West who decry the ugly sides of American capitalism and imperialism (narcissism, selfishness, crass materialism and consumerism, ultra-individualism, national chauvinism, and 
exclusivism-exceptionalism) often fail to realize and correct for the fact that we were raised in this culture, and, like a fish swimming in toxic sludge, we cannot but help to acquire some of the forms of imperial and capitalist cultural pollution in our own beings and lives as well. We all have to struggle against that which is within us that comes from the system we live under even as, or actually especially as, we decry that system.

We see, for example, demonstrations pushing for causes and places geographically distant and "safe" (e.g., "Free Tibet" and to support the so-called Dalai Lama) places by demonstrators who could not find the places they are raising notice of on a blank map. I have given extra-credit assignments for my students to interview demonstrators supporting movements in other countries (at both right and left demonstrations) and to give them a basic questionnaire, including a blank world map, about the geographic location and features of the foreign societies they are demonstrating their concerns about. The levels of ignorance revealed in the results were profound. So we find nominal leftists protesting US debt and dollars, held by China in particular, as some kind of existential threat per se; but I have seen not one word about the fact that no one in China forced anyone in America to borrow or the fact that historically China, including after 1949, has been a victim, and never a source, of imperialism, colonialism, debt peonage, encirclement, or terrorism.

\section{Central Contradictions of Capitalism}

Xinning Zhang: Rather than taking responsibility for the financial crisis which had caused great suffering to people since the beginning of OWS, the super-rich still enjoy favorable salaries and welfare. Data from the Center on Budget and Policy Priorities showed that shares of total incomes taken by the wealthiest $1 \%$ have been raised since 1980 and peaked at $23.5 \%$ in 2007. Though the number has somewhat reduced a bit after the financial crisis, it remained $20 \%$, which illustrates the realities of US income and wealth gaps. The US unemployment rate of last August reached $8.1 \%$. The unemployment rate in America has amounted to $>8 \%$ in the official rate for the past 43 months. The United States Census Bureau released its latest survey of poverty in America on September 12 [2012], revealing that the ranks of those classified by the government as poor remained at record highs in 2011, while the gap between the rich and everyone else widened further. The annual Census report recorded a decline in median income for the second year in a row; a fall in workers' wages, and a sharp increase in the number of workers holding down full-time jobs at near-poverty wages. Some demonstrators showed their dissatisfaction with the current situation and uncertain prospects.

During the demonstration on the first anniversary of OWS, some protesters said that nothing had changed in the past year; "the super-rich still control the 
US economy and Wall Street stands still." Some demonstrators claimed that "the super-rich on Wall Street are our common oppressors and 1\% of the population has robbed the wealth of us $99 \%$. We honor the first anniversary of OWS by making our own voices heard." What do you think is the primary contradiction in the development of American economy and society? How to analyze such contradiction?

James Craven: One of the central contradictions of capitalism (related to the primary contradiction of advanced capitalism between the further development of the productive forces, on the one hand, versus the increasing relative backwardness and retarding force of existing and evolving relations of production, on the other hand) is made more intense with the ripening of capitalism into the stages of monopoly capitalism and imperialism. This is the contradiction between the imperative for and production of surplus value, on the one hand, versus or against the imperative for and realization of that same surplus value, on the other hand.

To produce maximum possible surplus value requires, and leads to, among workers: specialization; integration; coordination and cooperation; interdependence; holistic and systems thinking and planning; ability to delay immediate gratification and reward; discipline and sustained focus; sacrifice for the collective; agenda and goals collectively set and pursued in concert, etc. These same behavioral traits and values are also required for the planning and logistics of successful demonstrations and the development of Moments beyond mere Moments, into sustainable Movements that have any chance of impacts beyond their time and place. But the realization of maximum possible surplus value (that is only potentially embodied in the production of it in the commodity produced, but not yet actually realized from and when the actual sale of the commodity and the actual receipt of revenues from all accounts receivable cleared) requires a different and even contradictory set of proclivities and values on the part of those who actually buy, pay for and use the same commodities. Capitalism not only requires mass production but also mass consumption — and by those with the means to actually buy and also pay for (two distinct processes with credit and debt involved) commodities sought and bought. The actual realization of the surplus value only potentially embodied in the production of the commodity (when produced at the lowest possible total private costs relative to expected or potential revenues) only occurs with effective demand translated into actual sales that bring home profits that actually accrue, actually received, when all accounts receivable have been cleared. So the imperatives that create mass production of surplus value also produce the wealth and income inequalities that retard mass consumption and the actual realization of embodied potential surplus value.

The type of person needed under capitalism for the ongoing and expanding markets and purchases and for the realization surplus value is one who is typically: egoistic; impulsive; individualistic; wants it all and wants it now; unable to delay gratification; 
ultra-individualistic and competitive; selfish; materialistic and acquisitive; shallow and obsessed with fads and materialism; irrational; narcissistic; willing to go into debt to have it now; irrational in terms of assessing real costs and benefits; etc. This is NOT the type of person, however, that one wants in combat in the military, as a spouse or in-law, as someone in a position of trust, as, say, a physician. This type of selfish, egoistic, competitive, and individualistic "Economic Man" stands in stark contrast and contradiction with the kind of worker and person needed for the production of maximum possible surplus value: disciplined; focused; non-impulsive; able to delay gratification; cooperative; able to sacrifice for the team; rational and steady; socially as well as individually oriented, calculates true and long-run costs and benefits and risks, not just immediate and short-run costs versus benefits.

This same kind of contradiction shows up in the OWS demonstrations between the production of mass demonstrations intended and likely to have real and lasting mass effects on mass populations (requiring leadership, structure, agenda, tactics and strategy, cooperation, surrender of egos, coordination, compromise on agenda, etc.) versus the actual results that appear to have been achieved and realized in these demonstrations so far, as evidenced by variations in numbers and the extent to which, say, weather affects their turnout numbers. Demonstrations intended to produce impacts on policies and issues and show solidarity on a range of commonlyagreed-upon issues, are undermined and sabotaged by: egotism; sectarianism; single issues; lack of planning and logistics; a carnival-like atmosphere; petit-bourgeois libertine behaviors such as dope smoking, drinking alcohol, open sex, and other forms of behavior; infantile theatrics, and alienating the public support; mindless violence and property destruction; etc.

What often shows up in demonstrations in the West, particularly in America and Canada, is a mélange of single issues and single-issue demands, pushed by individuals or small sub-groups, often dressed provocatively, with their own agenda and emotionally gratifying theatrics, like a cacophony of loud and even opposing voices drowning each other out. We see windows of stores and banks smashed, non-participants in the demonstrations turned off and not even one word as to why a particular bank is chosen to have its windows smashed and how that might educate and mobilize "the masses" to "join in"-and to "join in" what, exactly?

Xinning Zhang: Some scholars argue that OWS has somehow made an influential impact on American society. They see demands for social justice and equality have increased and enjoyed popular support. As for the demonstrators of OWS, Occupy is itself seen as a "movement" and now, in retrospect, an institution. They see OWS and other Occupy demonstrations around the US as embodying democratic practices, during which problems, targets, and strategies are discussed democratically, as are tactics. As to the US government, it has also begun to focus on the problems 
shown in OWS. How do you regard such kinds of changes on the part of the public and government?

James Craven: These demonstrations are costly for the state to cover and make arrests, which elements of the state are often able to turn around against the demands by protesters for more not fewer public programs to redress the ugly sides of capitalism. We hear an accounting of the stretched public budgets and resources lost for those programs being advocated, allegedly due to the costs of covering the demonstrations themselves. Often the timings of the protests also guarantee that few currently employed persons at work are able to join in, thus giving the impression that the protests are only by those directly interested in: jobs - for themselves and their families; their personal student loans; their personal mortgages; their personal right to serve in the military even in imperialist wars regardless of sexual orientation; their right to marry whom they love; their right to cheap oil and gas; their right to lower tuition fees and lower interest rates on student loans, etc.

Two to three years ago, there was no real mention of wealth and income inequalities in America or globally between nations in the demonstrations of the time. The slogan of the $99 \%$ versus the $1 \%$ was not a common meme. There is some vague notion that wealth and income inequalities that are "too unequal" are problematic in some amorphous ways but little specifics or analysis of how and why. If you ask those whose signs protest wealth and income inequalities in America (few mention globally) specific questions about their demands and why, few can answer. What is the difference between wealth and income? What are the constructs like Gini coefficient used to measure wealth and income inequality and what do they hide? Why do wealth and income inequalities become self- as well as mutuallyreproducing and reinforcing? How do they affect structures of aggregate demand and supply, investment, employment, money supply and demand, saving, lending, commodity prices, intersectoral flows that are often more important than actual levels or volumes of those flows? What happens when access to political power is itself a commodity for sale and wealth-income inequalities widen? How do wealth and income inequalities feed and reinforce each other and how are they measured?

The impression that appears to be conveyed is that these demonstrations are mostly outlets for anger, reaction, fear, envy, feelings of impotence, and a range of other emotions. Demonstrations can be useful; but they can never substitute for, and in fact can be calculated diversions from, the hard and protracted work of organizing, recruiting, fundraising, self-education and the education of others, planning, linking-up and movement building and consolidation of a united front against fascism, imperialism and war, which is our main mandate today in today's world facing today's crises and their fundamental origins. 


\section{Development and Direction of the Movement}

Xinning Zhang: 99\% and 1\% appears to have been the most resonant slogan chanted. It shows that the $99 \%$ has united to protest the 1\%. The most impressive scene the OWS has left for us is the anger of demonstrators against social inequality. "We are the 99\%" has proved to be most resonant. On the protesters' website in Seattle, the "movement" is referred to as "a leaderless protest by people of different colors, genders and political beliefs." "The only common thing we share is: we make up 99\% of the society and we can no longer bear the greed and corruption of the 1\%." A fairly interesting thing happened in Boston: hundreds of Harvard students started an occupation of Harvard yard. They staged a walkout of Prof. Greg Mankiw's popular class of Economics 101 lecturing on income inequality to protest what they saw as biased teachings. What do you think of the protest of $99 \%$ against the $1 \%$ ?

James Craven: Bertolt Brecht once noted: "In the contradiction lies the hope." Here he notes basic principles of dialectics that (1) all things possess and are made up of unique contradictions, opposing forces and tendencies, that make up a unity or whole of internal opposites, the struggles and balances of which drive the phenomenon in which they reside and that they define; (2) internal contradictions are the basis of change and external forces are conditions of change; (3) all things are in process, from simple to higher orders of complexity, and in each phenomenon or whole system, the same forces and contradictions that produce change and development eventually come into contradiction with the further development and existence of the phenomenon - the negation of the negation - as construction and deconstruction are dialectically related as each is requisite to, and defines, the other.

But to plan and harness forces and processes of destruction of the old that are requisite for construction of the new is no easy matter. Growth, development, progress, liberation, and all of history itself are not smooth, linear, exponential, unidirectional, upward (from barbarism to "civilization") processes. They often involve two steps forward for one step backward; they may also involve two steps backward for every one step forward; they may involve leaps of alleged "stages" and sequences of stages; they may involve total regression back to conditions that existed hundreds of years in the past. But it is clear that "It is better to know where to go and not know how, than it is to know how to go and not know where." It is core interests and values that inform vision; it is vision that informs strategy; it is vision and strategy that inform and set mission. Often it is the other way around, given as mission, vision and values rather than values, vision and mission.

On this first question on the state of the "Moment" and if it can turn into a "Movement," let's discuss the central meme (thought virus) of the alleged 99\% 
against the top $1 \%$ of wealth and income holders. On one level it focuses more on class than on the other dimensions and forms of exploitation, division and inequality under imperialism: gender; age; race; ethnicity; religion; urban versus rural; mental versus physical labor, etc. That is welcomed and needed. The fundamental basis of oppression under capitalism is and always has been class. And within class we find other forms of oppression based on gender, race, ethnicity, religion, sexual orientation, etc.

But as shorthand, this mythical " $99 \%$ " leaves a lot to be desired because it gives an impression of essential intra-class homogeneity as well as interclass non-adversarial relations, and hides profound contradictions among and within the top $1 \%$ as well as the bottom $99 \%$. Among those $99 \%$ are those among the lumpen-proletatiat by choice - criminals, psychopaths, and sociopaths who have historically been recruited as thugs by the $1 \%$. There are petit-bourgeois intellectuals who will trade the illusion of their personal security and safety for their illusion of liberty and creature comforts. There are management types who will downsize their own mothers and fathers for job security and a promotion. And there are among the $1 \%$ some who have more of a sense of capitalism as an historical mode of production and stage of human history rather than a permanent and highest stage of human achievement. This $1 \%$ versus the $99 \%$ meme may be useful in some organizing, but it glosses over a reality that is even more pronounced in the West than elsewhere - the increasing roles of superstructure, stratified labor power, and increasing sophistication of methods and instruments of superstructure, in the overall mode of production (monopoly capitalism) of the social formation (neo-imperialism) of the US.

By superstructure, sometimes called SSAs or Social Structures of Accumulation, or Social Capital, by others, we mean basically the politico-legal, sociocultural, historical-geographic dimensions (institutions, power relations and structures, contexts, traditions, laws and constraints, rewards and incentives, etc.) that shape and are shaped by the dimensions of the economic base made up of (1) forces and means of production and distribution of means of subsistence; (2) social, economic, and power (class and strata) relations between individuals and groups involved in production and distribution of means of subsistence; (3) Technology and various contexts within which technology is developed and applied.

And we know more and more, from history and science, that in all social formations and partly articulated modes of production that make them up, economic bases and superstructures are dialectically related with each fundamental to the other. Human beings cannot make art, literature, law, or anything unless they subsist; and they cannot subsist without an economic base that produces and distributes the means of subsistence. On the other hand, although economic and other aspects of reality exist objectively and independent of our consciousness of them, there is an objective reality even if we only get glimpses of aspects of that reality; we 
interact with all aspects of reality around us through the mind, and the constructs of the mind; and thus elements of superstructure condition and mediate all of our perceptions and reactions and interactions with the aspects of realities of which we are also integral parts.

In new studies of cognitive science, neurobiology and related disciplines, empirical evidence shows three fundamental facts: (1) the human mind is inherently embodied (in the human body and human physiology as well as in the various contexts under which one lives); (2) human thought is mostly ( $>95 \%$ ) unconscious and the unconscious processes shape and structure conscious thought; (3) abstract thought and constructs are largely metaphorical. The old notions of the Enlightenment of individualism, notions of pure "logic" and "thought and reason" outside of the human being, and of all the internal processes that mediate and shape thought within the human being, have been challenged by scientific work in brain science and cognitive psychology and other disciplines. These facts, however, have to be handled carefully as, for example, as early as 1907, Louis Boudin, in his The Theoretical System of Karl Marx noted that this kind of work in cognitive psychology (about the unconscious structuring the conscious, etc.) was being used to promote rank idealism and notions that there is no independent or objective reality outside of consciousness of it. But it does show we need to be increasingly mindful of just how constrained, and through what kinds of constraints, we humans are limited in the areas of cognition, reason, logic, science, and even overall "rationality." In many languages there is the same aphorism as in Chinese: "jin di zhi wa" or "for the frog in the well the sky appears only as big as the mouth of the well." We all live in wells of sorts, we all have limitations on our cognition and awareness of the elements of objective realities we are a part of, and we all need to be humbled by these facts in our mass work and interactions with different people from different perspectives on the issues of the day and how we ourselves are also shaped and limited by that which we decry and demand to be changed or eliminated.

That means that superstructure, and new SSAs and their effects on human consciousness, perception, cognition (including those weapons of mass distraction aimed at those who would be OWS protesters) and potential resistance to oppression, are the objects of attention increasingly by the forces of reaction - the ones controlled by that $1 \%$. This issue has to be taken seriously and it has not in my opinion been taken seriously enough up to this point. Again, we on the Left need to do serious self-examination and self-criticism of our slogans, methods of organization and protest, methods of teaching and learning, as well as of our own ideologies, memes and themes. We need to see that it is not just everyone else who is a product of and shaped by capitalism and imperialism, but that we are also among those also shaped by the very system we protest against; a system and its rewards of plunder from the periphery that accrue to many of us in the $99 \%$ at home in the metropolis of 
imperialism. We also need to keep in mind that, as the Nazis demonstrated clearly, it is quite possible for a relatively few to trick and induce the many that outnumber them by thousands to one, to literally walk to their deaths, and even take their loved ones with them knowing the fate that awaits them, rather than meet their certain fate on their feet in combat with their murderers. Throughout history, there are accounts of incredible courage. But also there are accounts of treason, cowardice, collusion due to the typical fears of human beings, of the unknown and uncertain, of death and of losing their relative if even meager privileges, having paralyzing and reactionary effects on humans and their willingness to get rid of their illusions and creature comforts. Institutional and cultural factors causing victims to be divided and not to resist the systems oppressing them more than favoring them that should never be underestimated and need to be examined scientifically.

Xinning Zhang: American intellectuals have been concentrating on OWS since its very beginning in September 2011. They have opened related courses, published articles and books, launched the Occupy Movement toward the social sciences field in America. The International Left Forum, with the theme of Occupy the System - Confronting Global Capitalism, held in Pace University, Lower Manhattan, New York, from March 16 to March 18, 2012, is a direct response to OWS from a global and historic sense. Recently, in retrospect, many American scholars showed insightful thoughts of the strengths and weaknesses of OWS in the past year. Some suggested that capitalist countries make significant economic transformations. Others considered that America may have to take a kind of modification path over the next ten years. Still some others claimed that we must set a moderate path for a brand new government. Some held that OWS is a victory and it has brought changes to American politics and culture and has motivated the conservatives; yet some others denied the significance of the movement. According to you, how will the movement develop and what about the direction of the movement?

James Craven: We see in America, and elsewhere, new research into areas of: "manufacturing [mass] consent"; interrogation; subliminal mind control and influence; memetics (how to effectively spread memes or thought viruses); brain science; operant and respondent conditioning; surveillance; mental illness and therapy; hypnosis; lie detection; optics and acoustics; psychological warfare; WMDs (including "Weapons of Mass Distraction" and "Weapons of Mass Division" and of "Mass Diversion"); chemical, biological and atomic tools, weapons and systems that are increasingly more lethal, compact, mobile, flexible, adaptable, covert, standardized, specialized, and terrifying when delivered. 
These and other "advances" in the hardware and software of the national security state and fascism are applied in various places but all have intended demonstration and applied effects on Americans as well as non-Americans.

Where Marx and others thought that the material conditions of advanced capitalism were necessary for workers to learn, in the workplace, attitudes, values and proclivities necessary for revolution (socialization and integration of productive forces forcing cooperation, solidarity, coordinated specialization, holistic and long-run thinking, etc.), Marx was not in a position in history, under existing conditions of advanced or ripe monopoly capitalism, to predict or analyze just how enticing, alluring, sophisticated, divisive, reactionary and lethal could be the distractions, opiates, sedatives, illusions, diversions, "tang yi pao dan" (sugar-coated bullets), "mian zhao" (masks), "divide-and-rule" mechanisms and reality escapes delivered by the SSAs or superstructures of monopoly capitalism; particularly American monopoly capitalism. This cannot be underestimated.

In my opinion, one of the great contributions of Mao Zedong to Marxism was not only to rescue some of Marxism from vulgar materialism, "stage-ism," onedirectional causality between base and superstructure, and vulgar slogan mongering; it was also to show the dialectical unity, mechanisms of articulation and disarticulation - "causality" - between elements of an integrated social formation and modes of production within it (economic, politico-legal, historic-geographic, sociocultural) and how elements and remnants of old modes of production shape and retard consciousness in the new social formations dominated by new modes of production. Mao Zedong also demonstrated dialectical unity and two-way interactions of the economic base and superstructure in modes of production and the wider social formations. Mao understood that all social formations or whole societies are dynamic complexes of interrelated modes of production, some of which are remnants of the past, one of which is the dominant and defining mode of production in the present — for now — and there are embryonic seeds of future modes of production to come. He also understood that forces and legacies, along with forms of consciousness of the past, act on and constrain the present, and what is tactically possible in the development of the economic bases in the present, in various ways including holding back new ideas and relations more suited to new realities.

In the case of the US and, I would say, Canada and Europe also, but the US to the greatest extent, where the creature comforts, distractions, promises, and credit to access some of the promises are most available, there is the part of the problem, and a major obstacle to development of a real national Movement beyond any Moment. One real obstacle to a national Movement against imperialism is that the more one has acquired materially and thus the more one has to lose, the more one is often driven not just to refuse to resist those who have granted token and illusory privileges, but either: (a) to fight more fiercely against losses of relative privilege 
as well as to threats and sources of threats of losses of relative privilege by reacting to, dividing from and aiding the repression of those with even less ("better them than me"); or (b) to compromise even more, to sell out others, to trade away some liberty and that of others for the illusion of some personal security and wealth, and also be willing to rationalize and defend having sold out more fiercely to mitigate losses and handle any cognitive dissonance angst. This "Faustian Bargain" is one of the oldest known in human history and was the basis for the aphorism by Benjamin Franklin: "Those who would trade away some personal liberty [and that of others] for [personal or loved ones'] security will neither attain nor deserve either." There is also the notorious "short memories" produced in America by the plethora of attention-grabbing, titillating, alluring and manipulative media, diversions, lies and toys pushed incessantly by monopoly capital.

I fear that rather than the notion of "the more advanced and ripe the capitalism, the more the material conditions for revolutionary thinking by the working class and the formation of a truly working-class party" being correct, it may well be the opposite case in some countries. I fear that the more advanced the capitalism, and thus the more pervasive, sophisticated and accessible the diversions, allures, lies, means of lying, distractions, sedatives, opiates, instruments of mind and soul control and manipulation passed on by superstructure and culture to the masses, the less, not more, likely revolution, revolutionary thinking or a genuine revolutionary Movement beyond some reformist Moments. And thus, as capitalism and imperialism ripen, the less, not more, the prospects for a revolutionary and transformative Movement; and the less, not more, the kinds of significant and immediate the changes imperative to prevent total collapse of the system and others around it, and to prevent total world war and even destruction of the whole planet.

I do not see much coming from some of the self-professed and apparently detached radical intellectuals. We often find them hiding under relatively safe names and labels like "Heterodox Economics," "New Political Economy," "Progressive Economics," "Marxian Scholarship" (like an archeologist of old and obsolete ideologies), and the like. They mostly write in journals even they do not read in total, let alone that are read and used by many others. They often write on subjects of personal interest in terms of building some academic market niche. They do little work in the field close to, or in venues frequented by, the subjects they write about. They seldom call back on those they have used for their "research" and notches on their CVs. They often write in stilted, formulaic and pretentious syntax, verbiage and vocabulary. Some of them, for example, without speaking a word of Chinese or ever having been to China, have all sorts of things to say and criticize about China; some of it right out of the Cold War vitriol of the 1950s, but often they appear to have nothing to say about what is going on right under their noses, on, say, American Indian reservations, in African-American ghettos, among exploited 
immigrants, among abused women and children, right up the freeways from their locations and in their name.

Not all of those in the $1 \%$ will remain there among the $1 \%$, and of those, not all will be a sworn enemy. On the other hand, not all of those in the $99 \%$ will prove virtuous, revolutionary or on the side of human progress and decency. Some of them will be thugs, criminals, sell-outs, poseurs, posturers, petit-bourgeois meme merchants, academic-turf-builders-and-protectors and the like. But I will bet on the fundamental contradictions of imperialism forcing all sorts of attitude and behavior adjustments without which no revolutionary change is possible or this planet and all of humanity on it are in deep trouble with little future ahead. Again, as Bertolt Brecht put it: "In the contradiction lies the hope." 